\title{
Penerapan Model Hellison Dan Pendekatan Soccer Like Games Dalam Meningkatkan Tanggung Jawab Dan Keterampilan Bermain Sepak Bola
}

\author{
*Husnul Afwa Elma Baisyah ${ }^{1}$, Didin Budiman ${ }^{1}$ \\ ${ }^{1}$ Program Studi Pendidikan Guru Sekolah Dasar Pendidikan Jasmani, \\ Fakultas Pendidikan Olahraga dan Kesehatan, Universitas Pendidikan Indonesia \\ email : husnulafwa@gmail.com
}

\begin{abstract}
Abstrak
Mayoritas siswa terlihat memiliki sikap tanggung jawab pribadi dan sosial yang rendah terutama ketika terlibat dalam pembelajaran dan permainan. Penelitian ini bertujuan untuk meningkatkan tanggung jawab dan keterampilan bermain sepak bola melalui penerapan model Hellison dan pendekatan soccer like games pada siswa kelas V SDPN Setiabudi Kota Bandung. Subjek penelitian seluruhnya berjumlah 35 siswa, yang terdiri dari 20 siswa putra dan 15 siswa puteri. Adapun metode penelitian yang digunakan adalah penelitian tindakan kelas (PTK), dengan GPAI dan lembar observasi perilaku tanggung jawab serta catatan lapangan dan dokumentasi sebagai instrumennya.Penelitian melibatkan dua siklus dan setiap siklus terdiri dari dua tindakan. Hasil analisis data dari siklus I dan II menyimpulkan bahwa tanggung jawab siswa meningkat dari $32,00 \%$ ke $86,29 \%$, dan keterampilan bermain siswa meningkat dari $54,19 \%$ ke $83,52 \%$. Berdasarkan hasil tersebut, dapat disimpulkan bahwa penerapan model pembelajaran Hellison dan pendekatan soccer like games dapat meningkatkan sikap tanggung jawab dan keterampilan bermain siswa dalam pembelajaran permainan sepak bola pada kelas V SDPN Setiabudhi Kota Bandung.
\end{abstract}

Kata kunci: Model Hellison, soccer like games, tanggung jawab, keterampilan bermain

*Husnul Afwa Elma Baisyah adalah lulusan Program Studi PGSD Penjas, Departemen Pendidikan Olahraga, Fakultas Pendidikan Olahraga dan Kesehatan, Universitas Pendidikan Indonesia. 


\title{
The Implementation Of Hellison Model And Soccer-Like Games Approach In Improving The Students' Responsibilities And Playing Soccer Skill
}

\begin{abstract}
The majority of children shown poor personal and social responsibility skills, especially when they were involved in learning large ball games activities such as football. This research was aimed at improving the personal and social responsibilities icluding children football skills in the games situation, with implementing Hellison model combined with soccerlike games approach on the fifth grader of SDPN Setiabudhi, Bandung. The subjects of this research were 35 students in total, consisting of 20 male and 15 female students. The research occupied a classroom action research, consisting of two cycles and 4 actions and employing GPAI (Games Performance Assessment Instrument) as the main instrument to assesst the skill competencies and behavior observation sheets as to assesst the responsibility behavior instrument, which also combined with field notes and documentation. As the CAR method has demmended, the steps of action to be done involving: planning, action, observation and reflection. The analysis result from cycle I and II concluded that the students' responsibility improved from 32,00\% to 86,29\% while the students' games skills improved from $54,19 \%$ to $83,52 \%$. Based on the result, it can be concluded that the implementation of Hellison model and soccer-like games approach can improve the students' responsibility and soccer game skills on grade V SDPN Setiabudhi, Bandung.
\end{abstract}

Keyword: Hellison learning model, soccer-like games, responsibilities, game skills.

\section{PENDAHULUAN}

Pembelajaran merupakan proses interaksi peserta didik dengan pendidik dan sumber belajar pada suatu lingkungan belajar yang meliputi guru dan siswa yang saling bertukar informasi. Dalam Kurikulum Tingkat Satuan Pendidikan (KTSP) disebutkan bahwa pendidikan jasmani adalah suatu proses pendidikan melalui aktivitas jasmani yang didesain untuk meningkatkan kebugaran jasmani, mengembangkan keterampilan motorik, pengetahuan dan perilaku hidup sehat dan aktif, sikap sportif, dan kecerdasan emosi. Pemberian materi pendidikan jasmani yang terlalu 
menekankan pada teknik juga akan membuat siswa merasa mengalami kesulitan yang berakibat pada rendahnya keterampilan bermain siswa.

Keterampilan seharusnya mendapat perhatian pada tingkat awal, dan pengajarannya berlangsung secara berkesinambungan. Keterampilan adalah keahlian yang dimiliki oleh seseorang untuk mampu menggunakan kreatifitasnya dalam mengerjakan atau menyelesaikan sesuatu. Keterampilan pada dasarnya akan lebih baik bila terus diasah dan dilatih untuk menaikkan kemampuan sehingga akan lebih menguasai sesuatu. Keterampilan (skill) adalah kegiatan yang memerlukan praktek atau dapat diartikan sebagai implikasi dari aktivitas (Nadler, 1986). Sedangkan bermain adalah aktivitas yang menyenangkan, serius, dan sukarela, dimana anak berada dalam dunia yang tidak nyata dan sesungguhnya. Bermain bersifat menyenangkan karena anak diikat oleh sesuatu hal yang menyenangkan, dengan tidak banyak memerlukan pemikiran (Furqon, 2008).

Permainan sepak bola adalah suatu permainan yang dilakukan oleh sebelas orang dengan cara menendang bola, yang mempunyai tujuan untuk memasukkan bola ke gawang lawan dan mempertahankan gawangnya sendiri agar tidak kemasukan bola dari regu lawan dengan aturan-aturan tertentu. Tidak bisa dipungkiri, hubungan sepak bola di penjas sekolah sangat erat kaitannya. Bagaimana tidak, hampir ditiap sekolah setiap pembelajaran penjas siswa laki-laki cenderung meminta bermain sepak bola bahkan pada jam istirahat pun, siswa laki-laki khususnya cepat berhamburan menuju lapangan sekolah hanya untuk sekedar bermain bola saja. Mereka sangat antusias dan bersemangat tinggi dalam bermain 
sekalipun alat yang mereka gunakan sangat sederhana. Namun kebanyakan fakta di lapangan siswa yang sudah mahir bermain sepak bola tampak antusias ketika pembelajaran sedang berlangsung, akan tetapi bagi siswa yang kurang mahir bermain sepak bola, mereka cenderung kurang bersemangat dan begitupun dengan siswa perempuan yang kebanyakan kemampuan bermain sepak bolanya kurang terampil, mereka tidak terlalu memperhatikan jalannya permainan.

Perlu adanya modifikasi pembelajaran sepak bola supaya siswa lebih tertarik untuk ikut bermain yaitu dengan menggunakan permainan soccer like game. Permainan soccer like games ini adalah aktivitas pembelajarannya yang dimodifikasi, baik peraturan bermain, alat atau bola yang digunakan, lapangan, cara membuat point, cara memulai permainan, jenis permainan, gawang yang berbeda dan jumlah pemain. Dengan soccer like games diharapkan partisipasi belajar siswa dapat meningkat karena soccer like games tidak hanya diminati siswa laki-laki saja, tetapi siswa perempuan dapat ikut terlibat untuk berperan serta dalam aktivitas pembelajaran. Sehingga semua siswa merasa dilibatkan dalam kegiatan pembelajaran tanpa terkecuali.

Sejalan dengan permasalahan pembelajaran penjas di atas, hal lain yang juga perlu mendapat perhatian kita semua adalah persoalan bagaimana penjas mampu mendidik anak dari sisi karakter moral, diantaranya terkait dengan sikap positif dan tanggung jawab anak, paling tidak ketika terlibat dalam pembelajaran penjas di sekolah. Salah satu fenomena yang menarik pada zaman modern di Indonesia adalah pemahaman dan implementasi tentang nilai-nilai moral dalam kehidupan masyarakat kita. Banyak sekali 
permasalahan yang menyangkut tentang hilangnya nilai-nilai moral dalam segala aspek kehidupan bangsa indonesia. Tidak hanya dalam dunia politik saja, tetapi sudah mulai merambah ke dalam dunia pendidikan dan kehidupan sosial bangsa. Dalam aspek pendidikan dan kehidupan sosial saat ini adalah tingginya angka tawuran antar pelajar, narkoba, seks bebas, pelecehan seksual, perang antar desa/kampung dan masih banyak lagi masalah yang terjadi dalam kedua aspek tersebut. Pada intinya semua contoh permasalahan yang telah dipaparkan diatas disebabkan kerana rendahnya nilai-nilai moral sebagian individu masyarakat bangsa kita dan salah satunya merupakan pengaruh dari rendahnya rasa tanggung jawab individu kepada diri sendiri, keluarga, masyarakat, bangsa/negara maupun tanggung jawab kepada Tuhan YME.

Para orang tua dan pihak sekolah harus menyadari bahwa mereka mempunyai tugas secara bersama dalam mengembangkan rasa tanggung jawab siswa dalam hal yang lebih positif. Peran orang tua di rumah seperti perhatian, kasih sayang, pendidikan dan motivasi mempunyai pengaruh yang sangat besar bagi tumbuh kembang rasa tanggung jawab sang anak. Pihak sekolah pun ikut andil bagian dalam mengembangkan rasa tanggung jawab siswa. Pihak sekolah yang didalamnya terdapat seperti kepala sekolah, guru mata pelajaran, wali kelas, bimbingan konseling, pihak keamanan dan lainnya mempunyai tugas dalam mengembangkan rasa tanggung siswa.

Pada dasarnya pelajar adalah manusia unggul yang sedang berada pada periode emas masa hidupnya. Mereka memiliki totalitas yang maksimal ketika melakukan pikiran, ide, gagasan serta perilaku yang masih sangat 
dibutuhkan sebagai modal untuk membangun bangsa yang maju dan masyarakat yang bermoral serta berbudi pekerti luhur. Mengingat pentingnya rasa tanggung jawab pada diri seseorang, maka sifat tersebut akan sangat menjadi lebih baik jika ditanamkan pada diri seseorang sejak ia masih dalam usia dini dan dilanjutkan secara terus menerus sampai tumbuh menjadi dewasa kerena mampu menumbuh-kembangkan perilaku. Banyak cara yang dapat dilakukan oleh orang tua, guru, masyarakat atau orang dewasa lainnya untuk mengembangkan rasa tanggung jawab kepada diri setiap individu, khusunya yang dapat dilakukan guru pendidikan jasmani saat melaksanakan proses belajar mengajar dalam mata pelajaran penjas. Secara spesifik dalam mata pelajaran pendidikan jasmani terdapat salah satu model pembelajaran yang bertujuan untuk mengembangkan rasa tanggung jawab siswa, yaitu dengan menggunakan model pembelajaran Hellison.

Terkait permasalahan penjas di atas tentang tanggung jawab, dari pengamatan penulis terhadap proses pembelajaran penjas di beberapa sekolah, khususnya di SDPN Setiabudhi kota bandung, ditemukan permasalahan masih rendahnya sikap tanggung jawab siswa ketika proses pembelajaran berlangsung seperti tidak memakai pakaian olahraga pada saat jam pelajaran penjas, mengganggu teman, tidak mau berbagi alat, dan lain-lain. Kondisi pembelajaran demikian, jika dibiarkan dan tidak mendapat perhatian yang memadai, akan menjadikan makin jauhnya tujuan penjas dalam mendidik anak untuk dapat dicapai. 


\section{METODE}

Metode penelitian dalam penelitian ini menggunakan metode penelitian tindakan kelas (Class Action Research). Penelitian tindakan kelas (PTK) adalah penelitian yang dilakukan dengan tujuan memperbaiki mutu praktik pembelajaran di kelas (Kunandar, 2012, hlm. 45). Subjek penelitian seluruhnya berjumlah 35 siswa, yang terdiri dari 20 siswa putra dan 15 siswa puteri. Adapun Instrumen yang digunakan menggunakan GPAI dan lembar observasi perilaku tanggung jawab serta catatan lapangan dan dokumentasi sebagai instrumennya.

\section{HASIL DAN PEMBAHASAN}

Model Hellison merupakan suatu model pembelajaran yang sering digunakan untuk membina disiplin siswa, untuk itu model ini sering digunakan pada sekolah-sekolah yang bermasalah dengan kedisiplinan para siswanya. Maka dari itu sikap tanggung jawab siswa dalam pembelajaran pendidikan jasmani sangat penting untuk mencapai tujuan pembelajaran. Karena dengan terciptanya sikap tanggung jawab, berarti siswa sudah peduli terhadap lingkungan serta ikut berpartisipasi dalam hal yang positif. Tanggung jawab adalah suatu keputusan atau perbuatan yang dilakukan seseorang di lingkungannya, dengan menanggung segala resikonya (Lutan dan Sumardianto, 2000). Sikap bertanggung jawab juga memiliki kaitan yang erat dengan karakter seseorang. Lickona (1992,hlm. 34) melihat hubungan ini sebegai berikut "character based on respect and responsibilty" dan karakter manusia dapat terbentuk melalui penjas dan olahraga (Arnold, 1994). 
Sikap tanggung jawab menjadikan suatu acuan penting dalam rangka meningkatkan kualitas keberhasilan suatu pembelajaran. Hal ini sesuai dengan hasil penelitian yang sudah dilakukan dari siklus I sampai siklus II. Pada siklus I tindakan I sebagian besar siswa sikap tanggung jawabnya masih rendah karena terlihat pada saat pembelajaran berlangsung siswa masih banyak yang mengobrol sendiri tidak memperhatikan saat guru menjelaskan, kurang aktif bergerak, mengganggu teman dan lain-lain. Pada siklus I tindakan II siswa mulai sedikit mengalami peningkatan perubahan perilaku ke arah yang lebih baik, yang artinya siswa sudah mulai mengerti sikap tanggung jawab. Hal ini terlihat dari perubahan sikap sebagian besar seperti sudah tidak ada yang mengobrol pada saat guru menjelaskan materi, sudah tidak ada yang mengganggu temannya, tetapi masih ada beberapa siswa yang cenderung kurang bersemangat dan kurang berpartisipasi aktif dalm pembelajaran.

Selanjutnya, pada siklus II tindakan I siswa kembali mengalami perubahan perilaku ke arah yang lebih baik terlihat dari level perilaku dan presentase siswa yang terus meningkat tindakan demi tindaan yang telah dilakukan, yang artinya siswa mulai mengerti dan sudah mulai bisa membedakan tentang perilaku tanggung jawab yang baik dan yang buruk tanpa harus diingatkan oleh guru, selama proses pembelajaran siswa sudah mulai membantu guru membawa dan menyiapkan alat pembelajaran, mulai membantu teman yang belum bisa melakukan tugas geraknya dan bahkan memberikan semangat kepada teman-teman lainnya. Sehingga membuat pembelajaran menjadi kondusif dan teratur. 
Pada siklus II tindakan II, siswa mengalami peningkatan perilaku yang cukup baik. Hal ini dapat dilihat dari presentase dan perubahan perilaku siswa yang terus mengalami peningkatan bahkan pada siklus II tindakan II ini siswa sebagian besar berada pada level 4 (caring) sebanyak 16 orang mendominasi dari jumlah siswa yang ada. Sikap siswa juga mengalami perkembangan dan perubahan yang cukup pesat jika dibandingkan pada saat awal-awal melakukan penelitian, pada siklus II tindakan II siswa terlihat sangat bersungguh-sungguh melakukan tugas geraknya dengan baik tanpa harus diperintah dan diawasi oleh guru, mau bekerjasama dengan temannya tanpa pilih-pilih, mebnatu teman, memberikan semngat dan membantu menyiapkan alat pembelajaran. Siswa terus mengalami peningkatan perubahan perilaku tanggung jawabnya ke arah yang lebih baik dari pra observasi, siklus I dan siklu II sampai hasilnya memenuhi target yang diharapkan. Hal ini terbukti dengan menggunakan model pembelajaran Hellison dapat meningkatkan perilaku tanggung jawab siswa pada saat proses pembelajaran dilihat dari hasil presentase dan perubahan perilaku semua siswa berdasarkan tindakan-tindakan yang telah dilakukan selama penelitian berlangsung.Salah satu bentuk modifikasi dari permainan sepak bola yaitu aktivitas soccer like games. soccer like games adalah permainan-permainan yang menyerupai permainan sepak bola dimana bentuk permainan nya dan peraturannya disederhanakan seperti ukuran lapangan diperkecil, jumlah pemain, bola, tiang gawang dan sebagainya. Soccer like game menyerupai permainan sepak bola, yang memiliki perbedaan terletak pada pendekatan permainan, bentuk-bentuk permainan serta aturan dan perlengkapan yang di modifikasi seluasluasnya yang memiliki beberapa unsur kekompakan, keterampilan, ketangkasan dan kegembiraan peserta didik dalam aktivitas pembelajaran. 
Berdasarkan hasil pengolahan dan analisis data menunjukkan bahwa penerapan aktivitas soccer like games berpengaruh terhadap peningkatan keterampilan bermain sepak bola siswa. Menurut Mahendra (2015a, hlm. 5) menjelaskan bahwa "keterampilan dapat menunjuk pada aksi khusus yang ditampilkan atau pada saat dimana keterampilan itu dilaksanakan". Hendrayana menjelaskan bahwa "Bermain adalah suatu kegiatan yang dilakukan secara sadar, sukarela, tanpa paksaan, dan tak sungguhan dalam batas waktu, tempat dan ikatan peraturan." Jadi yang dimaksud dengan keterampilan bermain adalah suatu keahlian tertentu yang dimiliki seseorang sebagai aktivitas gerak yang dilakukan dengan sukarela dan tanpa paksaan untuk memperoleh kesenangan dari aktivitas tersebut. Dari beberapa tahapan penelitian yang telah dilakukan dari pra observasi sampai dengan siklus terakhir berdasarkan data yang telah diolah dan dianalisis, terlihat bahwa siswa mengalami peningkatan pada setiap siklusnya sampai mencapai target yang diharapkan peneliti. Pada saat pra observasi keterampilan bermain siswa hanya mencapai 54\% yang artinya keterampilan bermain siswa masih tergolong rendah rata-rata belum bisa menyesuaikan diri dengan permainan yang diterapkan, hal ini terlihat pada saat pembelajaran berlangsung siswa mengalami kesulitan dan hambatan serta masih terlihat bingung pada saat melakukan tugas gerak yang diberikan. Pada siklus I tindakan I keterampilan bermain siswa mengalami peningkatan mencapai $64,76 \%$ siswa mengalami perkembangan dalam bermain sedikit lebih dibandingkan pada saat pra observasi, terlihat ada beberapa yang sudah mulai mampu mengeluarkan atau menunjukkan kemampuan (skill) yang dimilikinya saat permainan berlangsung. Selanjutnya, siklus I tindakan II dari hasil presentase keterampilan 
bermain siswa kembali meningkat mencapai 69,81\%. Pada tindakan II ini terlihat siswa sudah mulai terbiasa dengan permainan yang diterapkan oleh guru, tidak hanya itu siswa juga bahkan sudah mulai mampu bekerjasama dengan teman satu timnya, tidak terburu-buru mengambil keputusan seperti mengoper ataupun menendang dan terlihat bersemangat mengikuti pembelajaran serta menjalankan tugas gerak yang diberikan.

Pada siklus II tindakan I, keterampilan bermain siswa kembali mengalami peningkatan yaitu sebesar $76,48 \%$, perubahan terlihat dari sebagian besar siswa sudah mulai terbiasa dengan permainan yang diterapkan, lebih antusias dan bersemangat pada saat melakukan permainan baik siswa lakilaki maupun siswa perempuan. Selanjutnya, pada siklus II tindakan II peneliti merencanakan pembelajaran yang lebih menarik dan membuat simulasi permainan seperti mini soccer dan hasilnya keterampilan bermain siswa meningkat yaitu mencapai 83,52\%. Dari permainan yang diterpakan, siswa sangat bersemangat saat melakukan permainan yang diberikan baik siswa laki-laki maupun perempuan dan bahkan membantu serta mengajarkan temannya yang belum bisa menguasai tugas geraknya.

Dari penjelasan di atas, yang artinya jika dibandingkan pada saat awal penelitian terlihat keterampilan bermain siswa masih tergolong rendah namun setelah diberikan beberapa tindakan siswa mulai mengalami peningkatan yang cukup baik dari pra observasi, siklus I dan siklus II. Hal ini membuktikan bahwa keterampilan bermain sepak bola siswa kelas $\mathrm{V}$ SDPN Setiabudi kota Bandung dapat meningkat dengan menerapkan pendekatan aktivitas permainan soccer like games. Dari hasil pengamatan pra observasi, siklus I dan siklus II. Peneliti menemukan bahwa penerapan 
aktivitas permainan soccer llike games terutama dalam pembelajaran bola besar seperti sepak bola ataupun futsal sangat penting diterapkan di sekolah dasar. Karena permainan ini tidak baku yang artinya dapat dimodifikasi seluas-luasnya sesuai dengan sarana dan pra sarana yang ada serta kreativitas guru yang ada di sekolah tersebut, sehingga lebih memudahkan guru untuk dapat meningkatkan keterampilan bermain siswa.

\section{KESIMPULAN}

Berdasarkan hasil pengolahan dan analisa data dalam penelitian ini dapat disimpulkan bahwa melalui penerapan model pembelajaran Hellison dan pendekatan soccer like games dapat meningkatkan tanggung jawab dan keterampilan bermain siswa. 


\section{DAFTAR PUSTAKA}

Bahagia. (2010). Permainan Invasi Bandung : FPOK UPI

Berlian. (2009). Makalah: Pembelajaran Sikap Bertanggung Jawab Dan

Sikap Sosial Melalui Pendidikan Jasmani Di Sekolah Dasar. Bandung

Depdiknas. (2006). Kurikulum Tingkat Satuan Pendidikan. Jakarta: Depdiknas

Furqon, M. (2008). Mendidik Anak dengan Bermain. Surakarta: Universitas Sebelas Maret.

Hellison, D. (1995). Teaching Responsibility Through Physical Activity. United States of America: United Graphics.

Husdarta dan Saputra. (2000). Belajar dan Pembelajaran. Depdiknas. .(2000). Perkembangan Peserta Didik. Depdiknas.

Kunandar. (2008). Langkah Mudah Penelitian Tindakan Kelas. Jakarta: PT. Raja Grafindo Persada.

. (2012). Langkah Mudah Penelitian Tindakan Kelas Sebagai Pengembangan Profesi Guru. Jakarta: PT. Rajagrafindo Persada.

Lutan, R dan Sumardianto. (2000). Filsafah Olahraga. Depdiknas.

Mahendra, Agus (2007). Teori Belajar Mengajar Motorik. Bandung: FPOK UPI

Mahendra, Agus (2015a). Filsafat Pendidikan Jasmani: Dasar-dasar Pembelajaran Penjas di Sekolah Dasar. Bandung: CV. Bintang WarliArtika.

Mahendra, Agus. (2015b). Permainan Anak dan Permainan Tradisional. Bandung: CV. Bintang WarliArtika.

Priyanto, A. (2014). Internalisasi Nilai-Nilai Olahraga Melalui Pendidikan Jasmani Dan Olahraga Di Sekolah. Dikpora DIY.

Sucipto. (1999). Sepak Bola Depdiknas Dirjen Pendidikan Dasar dan Menengah Bagian Proyek Penataran Guru SLTP setara D-III-2000 . (2004). Pembelajaran Sepak Bola. Jakarta: Direktorat TK dan SD, Dirjen Dikdasmen Departemen Pendidikan Nasional. 